\author{
МИЛЕНА ИВАНОВИЋ* \\ Филолошки факултет Универзитета у Београду \\ Београд, Србија
}

\title{
СИНГУЛАТИВИ КАО ТВОРБЕНА КАТЕГОРИЈА У УКРАЈИНСКОМ И ЊИХОВИ ЕКВИВАЛЕНТИ У СРПСКОМ ЈЕЗИКУ
}

\begin{abstract}
Сингулятиви - словотвірна категорія іменників української мови із значенням одиничності. Сингулятивні іменники позначають один предмет, виділений із множинної сукупності або загальної маси. Наш аналіз охоплює: опис структури і семантики сингулятивів, їхнього відношення до інших лексико-семантичних груп іменників та їхню класифікацію в українській мові. Оскільки ця словотвірна категорія, характерна для східнослов'янських мов, майже відсутня в інших слов'янських мовах, то одним із завдань нашого дослідження вбачаємо виявлення відповідників українських сингулятивів у сербській мови.
\end{abstract}

Ключові слова: українська мова, сербська мова, одиничність, збірність, речовинність, сингулятив, партикуляризатор

Осврћући се у једном свом чланку на сингулативе у руском језику, А. В. Исаченко примећује да би Чеси и Словаци морали изучавати сваки појединачни руски сингулатив, будући да су лишени могућности да граматички схвате и правилно осмисле значење ових речи (Исаченко 1953: 202). Ова констатација једнако би се могла применити на однос било ког источнословенског језика са било којим језиком из групе западно- и јужнословенских, у којима је постојање сингулативних изведеница пре изузетак него правило (пољ. groszek, śrucina; чеш. bylina, květina; кашуп. graзэna, snéžэna; мак. лукче; срп. сламка; буг. бобовина, еновина, роїозина итд. $)^{1}$, а свакако и на украјински и српски језик, који су предмет нашег интересовања.

У сингулативе се неретко сврставају (Ковалик 1958; Горпинич 2004; Дабић 2000; Тихонов 2002; Peti 2001 и др.) и тзв. nomina nationalia и nomina regionalia са суфиксом -ин који функционише само у облици-

*ivanovic.milena@gmail.com

${ }^{1}$ Примери за пољски и кашупски преузети су од И. Ковалика (Ковалик 1958), за македонски од М. Ивић (Ivić 1983), а за чешки и бугарски од В. Горпинича (Горпинич 1999). 
ма једнине ових именица ${ }^{2}$ својствених, у већој или мањој мери, већи-

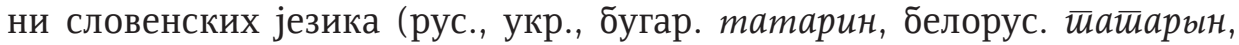
срп. Тайарин, мак. бблїарин, пољ. Tatarzyn итд.), при чему се истиче примарна сингулативна функција суфикса -ин у њима, из које се, како сматрају, на каснијим етапама развија значење припадности одређеној етничкој или територијалној групи (Ковалик 1958: 43; Романова 1966: 119). Будући да ове именице представљају инетерес пре за дијахронијско-компаративна проучавања него за контрастирање анализираних језика, оставићемо их по страни, иако их нећемо искључити из дефиниције сингулатива ${ }^{3}$.

Схватање сингулатива у славистици варира од уског, односно њиховог свођења на творбену категорију, што је карактеристично за проучавања источнословенских језика, до веома широког поимања сингулатива као конструкта, „облика који је у опреци према збирној именици, секундарно из ње изведеног”, „претпостављеног облика садржаја збирне именице" (Peti 2001: 225) ${ }^{4}$. Ми ћемо говорити о сингулативности као издвајању индивидуализованих, дискретних предмета из збирног скупа или градивне масе и сингулативима као једном од средстава таквог издвајања које се, осим на творбеном (укр. солома-соломина, срп. слама-сламка), може вршити и на лексичком (различитим значењима исте лексеме: бацийи камен - иревоз камена; кинути камінь-транспорт каменю, уз збирно камење и каміння, али и посебним лексемама - упор., на пример, украјинско сніт-сніжин(к)а, волосся-волосина, штани-штани-

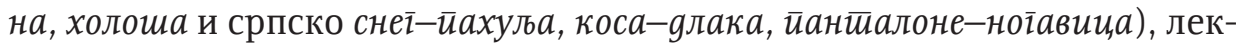
сичко-синтаксичком (помоћу тзв. партикуларизатора - упор. украјинско капуста-капустина, качан (голова) капусти и српско куйус-їлавии, $\kappa y \bar{u} y c a)$, али и на граматичком нивоу (у украјинском, флексија генитива једнине - $a /$-я код сингулативног значења лексеме и - $y /$-ю код збирног или градивног значења: вз'яти інструмента - набір інструменту). Свако од ових средстава захтева детаљније изучавање у оба анализирана

\footnotetext{
2 У украјинском би се ту још могле сврстати и именице люgина, guтuна, gівчина, будући да именице люgина и guтина имају суплетивне облике множине без суфикса -ин, а код именице gівчина облике множине gівчини, gівиин итд. практично замењују облици множине именице gівча - giвчата, gівчат итд.

${ }^{3}$ Оног њеног дела који се односи на лица.

${ }^{4} \mathrm{M}$. Пети тако говори о двема различитим парадигмама којима припада, на пример, именица сной и истиче да је реч о различитим семантичким положајима истог једнинског облика у саставу категрије броја. „У парадигми са збирном именицом облик сной није лексем, него њезин сингулатив, семантички облик једности онога што се њоме означује”, док је у парадигми сной-снойље у питању „опћа именица у једнини којом се означује једност" у опреци је са множином (Peti 2001: 228).
} 
језика ${ }^{5}$. Шта више, однос појединачно - мноштво није резервисан само за именице као врсту речи, срећемо га и код глагола (упор. мултипли-

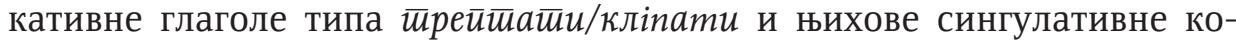

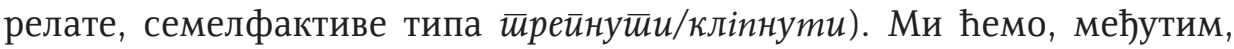
истраживање ове појаве почети у овом раду на материјалу творбених сингулатива у украјинском језику.

Сингулативи (лат. singularis - појединачан, посебан, јединствен; укр. сингулятиви, одиничні іменники) представљају, дакле, изведене именице којима се означавају предмети или лица издвојени из збирног скупа и/или градивне масе као појединачни примерци таквог мноштва. Овим именицама на тај начин се фактички опредмећује, индивидуализује беспредметна маса или скуп. Сингулативи као творбена категорија и лексичко-семантичка класа још увек нису довољно проучени у украјинском језику. Најчешће им је посвећено по неколико редака или пасуса у уџбеницима и граматикама (Ковалик та ін. 1969; Ковалик та ін. 1979; Горпинич 2004 итд.). Стога је примарни циљ нашег истраживања да попишемо, опишемо и класификујемо сингулативе у украјинском језику с обзиром на њихову творбену базу и семантику. С друге стране, будући да сингулативи као творбена категорија практично нису присутни у српском језику,

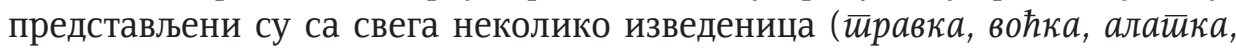
іраgљика, ирейљика), као други наш задатак видимо успостављање еквиваленције између украјинских сингулатива и средстава изражавања сингулативности у српском језику на другим језичким нивоима.

Пре него што приступимо анализи, осврнућемо се кратко и на разликовање сингулатива и сингулара. Најчешће се истиче да сингулар опонира плуралу, а сингулатив колективности ${ }^{6}$ (Дабић 2000: 200; Ко-

${ }^{5}$ У српском језику у изражавању сингулативности, односно квантификовању неизбројивог, најангажованији је лексичко-синтаксички ниво, те су најбоље проучени партикуларизатори (Ивић 1980; Ivić 1983; Пипер и др. 2005). Сингулативност се не односи на све врсте партикуларизатора, већ пре свега на оне који се квалфикују као „јединични уобличавачки партикуларизатори" (Пипер и др. 2005: 960). Сингулатив као творбену категорију у српском разматра Б. Дабић, који указује да је он „маркиран формантом - ин код именица мушког рода, и формантом -ка код именица женског рода" (Дабић 2000: 200). Дабићев рад посвећен је пре свега првом типу сингулатива, будући да у српском језику сингулативни деривати на -ка представљају пре изузетак него правило. За источнословенске језике, као што смо већ поменули, карактеристична је сингулативност изражена на творбеном нивоу, стога су најпроучаванији творбени сингулативи, пре свега у руском језику, док се остала средства посматрају из њихове визуре, те се, на пример, говори о сингулативима или простим сингулативима, с једне стране и описним (сложеним) сингулативима, с друге стране (Атанасова 2012: 14-16), односно о аналитичким сингулативима помоћу „посебних именица” (Ковалик та ін. 1969: 67).

${ }^{6}$ Тако Б. Дабић истиче да је опозиција сингулар-плурал изражена облицима Сpб-

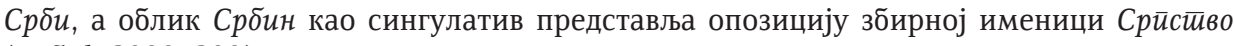
(Дабић 2000: 200). 
валик 1958: 23, 24), односно да сингулатив означава „оно што је појединачно”, а сингулар „оно што је једно” (Peti 2001: 214) и указује на маркираност сингулатива (Дабић 2000: 202; Ковалик 1958: 25). Ми ћемо сингулар посматрати као граматичку форму - у опозицији према такође граматичкој форми плурала, а сингулативност као значење јединичног, појединачног - у опозицији према мноштву (в. више о могућим комбинацијама односа у Пипер и др. 2005: 889), које може бити не само збирно, како се обично истиче, већ и, чешће, градивно, па и парно. Сингулатив као именица једно је од средстава изражавања сингулативности.

Нашим истраживањем обухваћено је 148 сингулатива са суфиксима -ина и/или -инка, од чега је 143 ексцерпирано из електронске варијанте једанаестотомног Словника української мови (СУМ) на основу претраге по кључним речима (окремиц̆, оgин, шматок, кусок, зерно, зернятко, зернина, стебло, стеблина и сл.), док 5 (бровина, gощинка, просинина, рисина, тесина) није забележено у речнику већ је преузето из секундарних извора. Постоје вероватно и сингулативи који се користе у разговорном језику, а нису забележени ни у речницима ни у литератури (до два таква - pegucuнa, йоміgорина - смо дошли анкетом спроведеном у друге сврхе, али их засигурно има више). И многи сингулативи у речнику маркирани су као разговорни (граgина, оgежина, пасльонина, рибина, стовоурина, товарина, травина, хуgобина итд.). Осим тога, поједини лексикографски забележени сингулативи не припадају књижевном језику већ различитим дијалектима (бучина, житина, пряgивина, скляничина, тертичина, тисина, торчина), а неки су маркирани као ретки (грабина, кровина, иматина, ягояина).

Суфикс -ина, осим сингулативног, изражава и друга значења, између осталог често и она супротстављена сингулативности: значење масе, материјала од кога се нешто прави (Горпинич 1999: 34): вербина, gеревина, кленина, мішковина, парусина и сл.; семантику збирности (Горпинич 1999: 145; Ковалик та ін. 1969: 39): іороgина, саgовина, ярина, озимина; као и апстрактна - просторна, временска и сл. значења (Ковалик та ін. 1969: 38, 43): глибина, давнина, новина, вершина, низина, височина, рівнина итд. Среће се и у називима појединих биљака (Ковалик та ін. 1969: 43): малина, ожина, калина, бузина. Интересантно је да све ове биљке представљају бобичасто воће а наведени називи истовремено имају и генеричку, и збирну, и сингулативну функцију, мада се за последњу чешће користи партикуларизатор ягоgа или деминутивни облик на -ка. Спој збирног и сингулативног значења уочава се и код других лексема: хуgобина (грло стоке и стока), хвоїна (иглица, четина зимзеленог дрвећа и грање четинара), сивинка (једна седа длака и седа коса), а посебно код једног специфичног типа сингулатива за означавање појединачног стабла дрвенастих биљака, који, осим сингулативног значења, 
неретко имају и збирно (и збирно-локативно) или градивно значење. Тако, судећи по речничким дефиницијама, лексема ясенина означава појединачно дрво јасена и - збирно, јасеново дрвеће, именице березина, gубина, соснина могу означавати и појединачно стабло брезе, храста или дуба, затим брезовину, храстовину или боровину као материјал, те брезову, храстову или борову шуму, а могу имати и партитивно значење, тј. означавати део дрвета - брезов, храстов или боров штап. Најзад, сингулативну (партитивну) семантику можемо уочити и код појединих апстрактних именица са просторним значењем на -ина као што је верщина чије значење речник дефинише као „горњи, највиши део нечега"7 (упор. на пример са низовина - „равничарски део копна (...)", височина - „узвишени део копна (...)" итд.).

У сложеном суфиксу -инка издвајамо сингулативни елемент -ин- и елемент -к- са деминутивним и хипокористичким значењем (Ковалик та ін. 1969: 44). Од 143 сингулатива које бележи речник, 67 функционише само са суфиксом - ина, 4 само са суфиксом - инка, док остали имају паралелне форме на -ина и -инка, при чему је форма са суфиксом -инка углавном ${ }^{8}$ маркирана као деминутивна или деминутивно-хипокористичка према форми са суфиксом -ина (бісерина-бісеринка, винограgинавинограяинка, gробина-gробинка итд.). Само облик са суфиксом -инка имају жиринка (са специфичним значењем „кап масноће на површини течности"), иукринка, иаїнка, сивинка $a^{9}$. Постојећа лексема сивина нема сингулативно значење, док бисмо код осталих одсуство паралелних твореница са суфиском -ина могли тумачити веома малим димензијама појединачних честица које се означавају сингулативом када не бисмо имали такве паралеле као што су піщина-піщинка. Међу сингулативима који имају само форме на -ина издвајају се они који означавају појединачна стабла дрвенастих биљака (берестина, бучина, вищнина, грабина, кеgрина, липина итд.) - ниједан од њих нема паралелну деминутивнохипокористичку изведеницу на -инка, што је највероватније повезано са димензијама ових појединачнох ентитета, који у принципу не могу бити

\footnotetext{
${ }^{7}$ Све речничке дефиниције овде и даље наводе се према електронској верзији СуМ.

${ }^{8}$ Углавном, али не и обавезно. Лексему сніжинка, рецимо, речник не дефинише као деминутив и хипокористик према сніжина (као што је то случај код већине именица на -инка), већ као основни сингулатив - „кристал снега у облику звездице”, док сніжина тумачи као „велика сніжинка". Нешто другачији однос имају лексеме рибина и рибинка: последња се дефинише као деминитувно-хипокористичко према $p u \delta u н a$, а речник указује и на њену збирну употребу, док се за именицу рибина истиче величина - „једна риба, углавном велика”. Најзад одређени број изведеница на -ина се дефинише као „исто што” и изведеница на -инка, што опет може указивати на то да је примарни сингулатив форма на -инка: пушина-пушинка, росина-росинка.

${ }^{9}$ Разговорно gощинка такође нема паралелну твореницу на -ина, а лексема gощи на није изведена од именице gощ, већ од именице gошка и значи „мала даска”.
} 
ситни. Слично би се могло закључити и за разговорне лексеме хуgобина и товарина које означавају грло стоке, као и за именицу капустина, будући да је главица купуса знатно већа од, рецимо, зрна грашка (горошина и горощинка), грожђа (винограgина и винограgинка), па и корена кромпира (картоплина и картоплинка) или главице лука (иибулина и иибулинка). Међутим, изведенице као што су бобина, коралина, мигgалина, сінина означавају ентитете знатно мањих димензија, а за њих речник такође не бележи паралелне облике на -инка. Овако сложени и испреплетени односи између именица на -ина и оних са сложеним суфиксом -инка наводе нас на закључак да су за избор суфикса колико битне димензије, толико, ако не и више, емоционално-експресивна компонента коју уноси елемент -к- у суфиксу -инка. У прилог оваквом закључку иде и чињеница да паралелне изведенице на -инка такође нема ни већина сингулатива са предметно-градивним значењем (сингулативи у ширем смислу - в. ниже): жерстина, кроквина, мостина, пряgивина, рогожина, скляничина, стелина, шкуратина итд. и које, осим што не могу бити сићушних димензија, такође не претпостављају било какав емоционално-експресивни однос према појму који означавају. Најзад, може се претпоставити и да речник код појединих лексема једноставно не бележи твореницу на -uнка, иако је њено извођење сасвим могуће.

Сингулативи најчешће корелирају са збирним (баgилля-баgилина, вугілля-вуглина, хуgоба - худобина) и градивним (пісок-піщина, иеглаuеглина) именицама. На граматичком плану сингулативи се одликују потпуном парадигмом броја и способношћу да се спајају са бројевима (gві баgилини, три картоплини, иотири сніжинки $)^{10}$. Последње готово без изузетка није карактеристично ни за градивне ни за збирне именице ( ${ }^{*}$ ва баgилля, ${ }^{*}$ чотири сніzи, али: три картоплі у значењу појединачних плодова): збирне именице немају облике плурала, док се потенцијални облици множине градивних именица ређе употребљавају и увек са специфичном функцијом (нпр. картоплі, пшенищі и сл. - у локативном

${ }^{10}$ Говорећи о прелазним случајевима у оквиру категорије броја у руском језику, В. Виноградов примећује да сингулативи имају облике оба броја, али да се у множини употребљавају готово искључиво с бројевима, речима као што су весь, никакой, многие, с предлозима који означавају количину, поседовање, лишавање, а без предлога само у функцији партитивног генитива: пять картофелин; несколько горошин; gвумя хворостинами; не gосиитаться многих тесин; все жемиужины оказались на месте и сл. (Виноградов 2001: 87). На исту појаву у украјинском језику скреће пажњу и И. Ковалик, указујући на то да се сингулативи не употребљавају у облику множине без бројева (Ковалик та $i$. 1969: 67). Исто тако се ни у српском партикуларизатори не употребљавају са бројевима, јер је њихова функција да учине бројивим оно што је у принципу неизбројиво или нема потребе за таквом квантификацијом - сувишно је рећи ољушйи іллавице лука када можемо рећи ољушиши лук, а ако је неопходно указати на количину, онда ћемо употребити

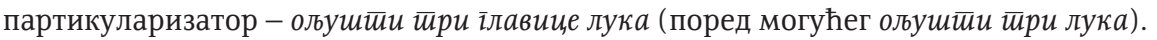


значењу места на коме је посађен кромпир, пшеница; сніт̈и, йіски и сл. - у значењу велике количине (масе) материје). Издвајајући појединачан ентитет из збирног скупа (градивне масе), сингулативи га опредмећују и тиме омогућују његову квантификацију.

Сингулативи се ређе изводе од именица са значењем регуларне збирности ${ }^{11}$, када исти корен имају и облик за јединичност, и збирна именица, и сингулатив, односно од оних које су у коралцији са регуларном множином: волос-волосся-волосина, вугіль-вугілля-вуглина, комаха-комашня-комашина и сл. Сингуларни облик се код ових именица или ређе користи од множинског (комаха $a^{12}$ ) или означава и, чешће, скуп ентитета, и појединачни ентитет (вугіль, волос), тако да, упркос постојању одговарајуће лексеме са пуном парадигмом броја, сингулатив ипак, због недвосмислене семантике појединачности, иступа као примаран облик за јединичност. Знатно више имамо сингулатива изведених од именица са значењем ексклузивне збирности (collectiva tantum), код којих је сингулатив једини облик којим може бити изражен појединачни припадник

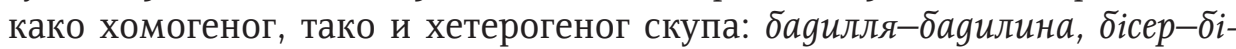
серина, віспа-віспина, gріб-дробина, ярова-дровина, зілля-зілина, насіння-насинина, одежа (оgяг)-о ежина, посуg-посудина, сміття-смітина, солома-соломина, худоба-худобина.

Збирним именицама семантички (значење целовитог скупа/масе) и формално (крња парадигма броја) су блиске градивне именице, а ову блискост потврђује и чињеница да се осим од збирних, сингулативи образују и од градивних именица. Блискост збирних и градивних именица истиче и М. Ивић, која под градивним појмом подразумева „све оно што се перцепира као некаква маса, а не као уобичајен предмет” (Ivić 1983: 15) и говори о градивно-збирним именицама на примеру лексеме слама, истичући да она означава „неку врсту неуобличене масе, слично блату или брашну”, али „за разлику од блата и брашна слама је ипак и својеврстан скуп уочљивих појединачних ентитета за које постоји и посебан назив сламка" (Ivić 1983: 15-16, в. такође Пипер и др. 2005: 961).

Лексичко-семантичка класа градивних именица обухвата велики број именица које означавају воће, поврће, житарице, траве и друге биљке, прехрамбене производе (иако се међу њима налазе и оне које се у граматичком погледу понашају као заједничке именице, односно имају пуну парадигму броја - рецимо, многи називи за воће - абрикоса, груша, gиня, персик, яблуко итд., поједини називи за поврће - баклажан, каба-

${ }^{11}$ Овде и даље термини као што су регуларна збирност, ексклузивна збирност, генеричка збирност користе се према дефиницијама датим у Пипер и др. 2005: 887-888).

${ }^{12}$ На ово указује речничка дефиниција која се даје управо уз множински облик комахи. 
иок, оїірок, йоміgор и сл.), различите врсте течности, хемијске елементе, руде, метале, грађевинске и друге материјале, лекове и сл. (Горпинич 2004: 44-45), а сингулативи се образују од оних код којих се преплиће градивно и збирно значење, при чему се из градивно-збирне масе мањевише јасно могу издвојити појединачни ентитети. Реч је о именицама које означавају поврће: біб-бобина, горох-горошина, капуста-капустина, картопля-картоплина, квасоля-квасолина, морква-морквина, переи,ь-периина, хрін-хрінина, иибуля-иибулина, иасник-иасничина; воће: винограg-винограяина, мигgаль-мигgалина, слива-сливина; житарице: жито-житина, овес-вівсина, пшениия-пшеничина, просо-просина, рис-рисина; друге, често самоникле биљке које расту густо или у жбуновима: бур'ян-бур'янина, лобоgа-лободина, мак-мачина, очерет-очеретина паслін-пасльонина, трава-травина; поједине прехрамбене производе: жир-жиринка, ікраікрина, иукор-иукринка, иай-чаїнка; различите врсте материјала, укључујући и тканине: волокно-волокнина, gріт-gротина, жерсть-жерстина, пісок-піщина, прядиво-пряgвина, шкура-шкуратина, шовк-шовковина итд. Овде би се могле сврстати и именице попут пил-пилина, порох-nорошина а градивно-збирно значење може се приписати и именицама које означавају различите врсте атмосферских појава: граg-граgина, gощ-goщинка, крига-кринина, лія-льодина, роса-росина, сніг-снінина.

Сингулативи се не образују само од оних именица које немају облике множине или је њихова употреба у плуралу ограничена, већ и од оних за које је карактеристично одсуство сингуларних форми или чешћа употреба у облику множине. То могу бити именице које означавају парне предемете штани-штанина, брови-бровина (поред сингуларног брова), нізgрi-нізgрина (поред сингуларног нізgря), предмете који се састоје од два - кроква-кроквина - или више истих делова: баляси-балясина, буси-бусина, коралі-коралина, штахети-штахетина (поред сингуларног штахет), именице са збирним - перли-перлина (поред сингуларног перла) или градивним значењем - коноплі-коноплина, крупи-крупина, uпроти-uпротина (поред сингуларног шпрот).

Изведенице са суфиксима -ина и/или -инка нису јединствене по свом значењу. Међу њима можемо издвојити неколико група. Сингулативи у ужем смислу означавају један од елемената од којих се састоји збирно мноштво или градивна маса. Реч је о најмањем видљивом делу ${ }^{13}$ који је концептуално једнак (по облику, величини и сл.) било ком другом делу таквог скупа или масе: бобина, волосина, горошина, gробина, пилина, піщина, соломина, иукрина итд. У ову групу сингулатива могу

${ }^{13}$ Најмањем у смислу језичке а не научне концептуализације стварности. За прву се, рецимо, вода састоји од мноштва капљица, а не мноштва молекула, јер молекули нису видљиви, те су недоступни непосредној спознаји. 
се сврстати и именице које означавају делове предмета који су по свим својим параматрима мање-више једнаки. Тако йаркейина означава једну летвицу паркета која је по саставу, облику, величини, боји једнака било којој другој летвици тог истог паркета; исто важи и за сингулативе типа мосиина, кроквина, сиелина, иет̈лина, намисиинна итд.

Сингулативи у ширем смислу означавају било који део збирног мноштва, градивне масе или сложеног предмета који се издваја у свакој конкретној ситуацији, а који је по свом саставу исти као други делови тог мноштва или предмета, али се од њих мање или више разликује по облику, величини и другим параметрима: вуглина, gротина, жерстина, льоgина, крижина, прядивина, рогожина, скляничина итд. Овај тип сингулативног значења можемо уочити и код именице жерguна, изведене из именице жерgb са истим значењем, као и код именице ключина које функционишу као мероними према именици gерево (чија изведеница са суфиксом - ина има друга, несингулативна значења) и означавају „дугачак, танак, без грана комад дрвета". Када збирна именица означава хетерогено мноштво, ентитет издвојен сингулативом близак је осталим елементима тог мноштва најчешће само по једном својству, углавном функцији: олежина, посуgина, смітина, худобина.

За сингулативе изведене од именица које имају пуну парадигму броја могло би се рећи да фактички само понављају функцију сингуларног облика. Ситуација, међитим, није тако једноставна. Тако, на пример, именица морква ${ }^{14}$ у облику једнине може изражавати генеричку семантику (вирошування моркви), имати збирно или градивно значење (принести моркву з магазину, торт з моркви) или означавати појединачан плод, односно корен шаргарепе (нарізати оgну моркву). У последњој функцији чешће се, међутим, употребљава сингулатив, будући да са значењем јединичности код њега не конкурише ниједно друго значење, те нам за разумевање конструкције није потребан контекст (упор. нарізати моркву (једну или више?) и нарізати морквину), нити је уз сингуларни облик сингулатива неопходна употреба броја оguн (упор. нарізати оgну моркву и нарізати морквину). Осим тога сингулатив морквина се слободно спаја са бројевима већим од иотири, који захтевају употребу генитива множине, што није случај са именицом морква (упор. ? n'ять моркв и n'ять морквин). И. Ковалик истиче да је „разлика у из-

${ }^{14}$ И многе друге именице које означавају поврће и, ређе, воће. Специфичности функционисања категорије броја код ових именица у појединим словенским језицима биле су предмет интересовања више научника (Ivić 1982; Ivić 1983; Wierzbicka 1988; Мустайоки 2006 и др.), али њиховим ни, колико је нама познато, другим истраживањима нису обухваћене ове именице у украјинском језику. Њихова анализа свакако би била од користи и за проучавање од њих образованих сингулатива, али за њу овде немамо довољно простора. 
ражавању јединичности речима зерно и зернина у томе што се у речима типа зернина јасно истиче јединична количина, а у речима типа зерно, које потенцијално садрже и збирно и јединично, јединичност је знатно слабије испољена (Ковалик 1958: 46). Тако именица зерно може имати збирно значење (срп. жийарице), може означавати „ситан плод житарица" (зерно кукуруязи), али и функционисати као партикуларизатор - „појединачан ситан део неке материје” (зерно кави, зерно конопель, зерно намиста). Сингулатив зернина употребљава се, разуме се, у последње две функције. И од других именица које функционишу као партикуларизатори образују се сингулативи којима се посебпо истиче јединичност: крапля-краплина, шматок-шматина, ягоgа-ягоgина. Значење јединичности посебно је истакнуто и код именица као што су сльозина, іскрина, стеблина, стовбурина, хмарина, иако именице од којих су изведени - сльоза, іскра, стебло, стовбур, хмара - немају збирно значење, па можемо говорити о сингулативима-појачивачима.

Сингулативи образовани од назива за воће и поврће означавају плодове, односно јестиве делове ових биљака. Сингулативи образовани од назива за житарице могу означавати јестиви део, то јест зрно (просина, рисина), или стабљику (сонячничина, хмелина), или и зрно и стабљику (житина, вівсина, пшеничина). О специфичној семантици сингулатива изведених од назива за дрвенасте биљке већ смо говорили у вези са значењима суфикса -ина. Називи од којих су изведени ови сингулативи обично уз генеричко значење, означавају и плод дате биљке, уколико га има (вищня, гліg, груша, черемха, черешня), док сам сингулатив означава стабло (вищнина, глоgина, груш(ев)ина, иеремшина, иерешнина). Овде ћемо још напоменути и да овакве изведенице чине петину ексцерпираних сингулатива, те да је код већине ипак присутно само значење јединичности (берестина, бучина, вишнина, глоgина, грабина, осокорина, рокитина, яблунина итд.).

У српском језику се сингулативно значење на творбеном нивоу изражава више него спорадично, те сви наши лингвисти који су се дотицали овог проблема указују да се овакве творенице образују само по изузетку (Дабић 2000: 202; Ивић 1980: 5; Ivić 1983: 16; Пипер и др.: 961). Број сингулативних лексема веома је мали, те творбене еквиваленте има тек неколико украјинских сингулатива: горошина - грашка; граgина - граgљика; жарина - жеравка (и жеравица); коноплина - конойљика; пилина, порошина - ирашка; соломина - сламка; травина - йравка, све са суфиксом -ка $(-u-\kappa a,-л ь-\kappa a)$. Суфикс -ика имају и поједине именице које означавају стабло одр. дрвећа, те украјинском соснина у српском језику може бити еквивалент именица борика („танко и витко борово дрво, млад бор” $)^{15}$.

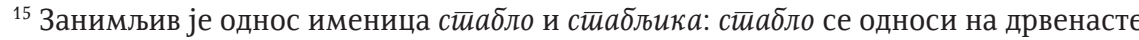
биљке, а сйабљика на травнате. У украјинском језику се за прво значење користи лексе- 
Део украјинских сингулатива преноси се лексички, посебним лексемама: бусинка, намистинка - иерл(ии)а; волосин(к)a - gлака, gлачи-

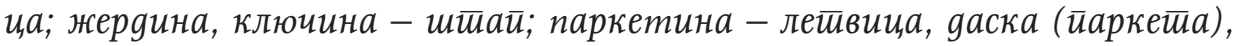

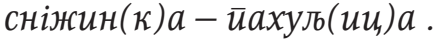

Најчешће се, пак, еквиваленти могу пронаћи на лексичко-синтаксичком нивоу, где је носилац сингулативног значења тзв. партикуларизатор - граматичка реч са функцијом издвајања дела из целине (Пипер и др. 2005: 959), и то тзв. јединични уобличавачки партикуларизатор. При преношењу украјинских сингулатива најзаступљенији је партикуларизатор зрно (зрнще), који има веома широку спојивост: боба (бобина), бисера (перлина), іраgа (граяина), ірашка (горошина), ірожђа (винограgина), жита а (житина), мака (мачина), овса (вівсина), йасуља (квасолина), иеска (піщина), ӣириниа (рисина), сачме (дробина), шећера (иукринка)

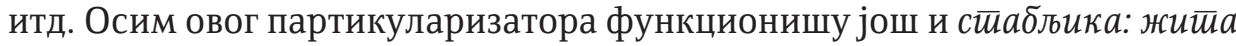

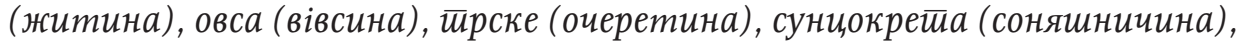
хмеља (хмелина); ілавица: куйуса (капустина), лука (иибулина, иасничи-

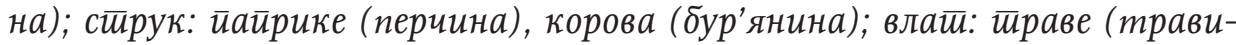
на), сена (сінина), итенице (пшеничина); тируниииа: сена (сінина), смећа (смітина); кай: кище ( оощинка), крви (кровинка), масти (жиринка), росе (росинка); комаg: леgа (льодина), оgеће (оденина), иосуђа (посуgина), стиакла (скляничина); иестиияа иррашине (пилина, порошина); ірумен уільа (вуглина), лисй лима (жерстина), ірло сйоке (худобина, товарина) итд.

Најзад, у појединим случајевима украјинској збирној именице одговара множински облик српског еквивалента, те се сингулатив преноси једнинским: упор. віспа и віспина према осиее, осиичие, боїиње и осйа, осйии, б, бог̈июа; хвоя и хвоїна према четине, чеииннари и чеиинна итд. Именице

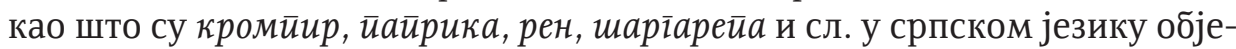
дињују у себи генеричко, збирно-градивно и значење плода одговарајуће

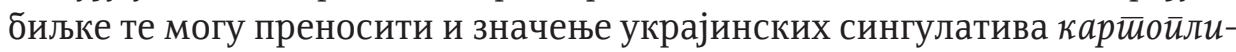
на, иерчина, хрінина, морквина или се то значење може пренети помоћу конструкције са партикуларизатором: корен шаріарейе, корен рена и сл.

Наше истраживање показало је да творбена категорија сингулатива у украјинском језику, формално обједињена суфиксима -ина и/или -инка, на плану садржаја јесте релативно разнолика и има неколико различитих семантичких типова. Састав творбене базе такође је разнолик, али највећи део ових именица обухвата лексеме које спадају у биљни свет, код којих се као појединачан ентитет издваја плод, односно јестиви део као концептуално најзначајнији за човека. Реч је углавном о сићушним плодовима у виду бобице, на шта указује и српски партику-

ма стовбур, а за друго стиебло и од обе се изводе деривати на -ина са значењем истакнуте сингулативности - стовбурина и стеблина. 
ларизатор зрно помоћу којег се најчешће успоставља еквиваленција са украјинским сингулативима. Што се тиче српског језика, преостаје нам само да потврдимо констатације изнете у претходним истраживањима да српски језик „мало искоришћава (...) могућност деривирања сингулативног образовања од збирно-градивног” (Ivić 1983: 16), те да „списак” творбених сингулатива који се у њима срећу проширимо са свега неколико изведеница. Поред сламка, ирравка (Дабић 2000: 2001; Ivić 1983: 16; Пипер и др. 2005: 961), воћка (Дабић 2000: 2001), сингулативно значење

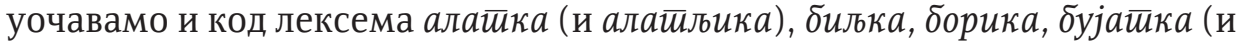
бујаяљика), іраяљика, ірашка, жеравка (и жеравица), јелика, конойљика, иоврћка (резговорно, аналогијом према воћка) ирашка, ирейљика, шащљика, щиб(љь)ика.

\section{ЛИТЕРАТУРА}

Атанасова И. Специфика сингулятивов, Folia Linguistica Rossica 8, 2012, 9-17.

Виноградов В. В. Русский язык (Грамматическое учение о слове), 4-е изд., Москва: Русский язык, 2001, 720.

Горпинич В. О. Суиасна украӥнська літературна мова. Морфеміка. Словотвір. Морфонологія: Навиальний посібник, Київ: Вища школа,.) 1999, 207.

Горпинич В. О. Морфологія української мови: Піяручник яля студентів вищих навиальних заклаgів, Київ: Видавничий центр «Академія», 2004, 336.

Дабић Б. Белешке о категорији јединичности у српском језику, Наш језик, 2000, 33, 3-4, 198-203.

Ивић М. О „партикуларизаторима”, Јужнословенски филолої, 1980, XXXVI, 1-12.

Исаченко А. В. О сравнительно-историческом изучении грамматических категорий в славянских языках, Slavia XXI, 1953, sešit 2-3, 200-213.

Ковалик I. І. Словотворча будова збірних і одиничних іменників у східнослов'янських мовах у порівнянні з іншими слов'янськими мовами (nomina collectiva et singulativa), Питання слов'янського мовознавства, 1958, кн. 6, 18-50.

Ковалик I. І., Матвіяс І. Г., Баранник Д. Х. та ін. Суиасна українська літературна мова. Морфологія (за заг. ред. І. К. Білодіда), Київ: Наукова думка, 1969, 583.

Ковалик І. І., Родніна Л. О., Грищенко А. П. та ін. Словотвір суиасної української літературної мови, Київ: Наукова думка, 1979, 407.

Мустайоки А. Грамматическое число у названий фруктов, овощей и ягод в русском и финском языках, Языковая личность: текст, словарь, образ мира. Москва: Изд. РУДН, 2006, 447-463.

Пипер П., Антонић И., Ружић В. и др. Синйакса савременоїа срйской језика. Простиа реченииа (ред. Милка Ивић). Београд: Институт за српски језик САНУ - Београдска књига - Матица српска, 2005, 1165.

Словник української мови, http://sum.in.ua/ 13.07.2017. 
Тихонов А. Н. Современный русский язык. Морфемика. Словообразование. Морфология, Москва: Цитадель-трейд, 2002, 423

Трубицина И. А. Словообразовательная категория имен существительных со значением еgиничности в современном русском литературном языке. Автореф. дис... кандидата филологических наук, Ставрополь, 2006, 24 с.

Романова Н. П. Словотвір. Іменники, Встуй gо порівняльно-історичного вивчення слов'янських мов (ред. О. С. Мельничук), Київ: Наукова думка, 1966, 113-174 c.

Ivić M. Slavic Fruit and Vegetable Names and Countability, International Journal of Slavic Linguistics and Poetics, 1982, XXV/XXVI, 209-211.

Ivić M. Lingvistički ogledi, Beograd: Prosveta, 1983, 225 s.

Peti M. Zbrojina, Rasprave Instituta za hrvatski jezik i jezikoslovlje, 2001, knj. 27, 209-250.

Wierzbicka A. The semantics of grammar, Amsterdam; Philadelphia: John Benjamins, 1988, $\mathrm{x}+617$.

\title{
Milena Ivanović
}

\section{SINGULATIVES AS WORD-FORMATION CATEGORY IN THE UKRAINIAN LANGUAGE AND THEIR EQUIVALENTS IN SERBIAN LANGUAGE}

\begin{abstract}
Summary
Singulatives are word-formation category of nouns in the Ukrainian language that refer to individual objects separated from the mass or collection of objects. The article is devoted to a study of the structure and semantics of singulatives, their relationship with other groups of nouns and their classification in the Ukrainian language. As this word-formation category is typical for East Slavic languages and almost absent in other Slavic languages, one of the goals of our research was to identify equivalents of Ukrainian singulatives in Serbian language.

Key words: Ukrainian language, Serbian language, singularity, collective nouns, material nouns, singulative, particularisator
\end{abstract}

